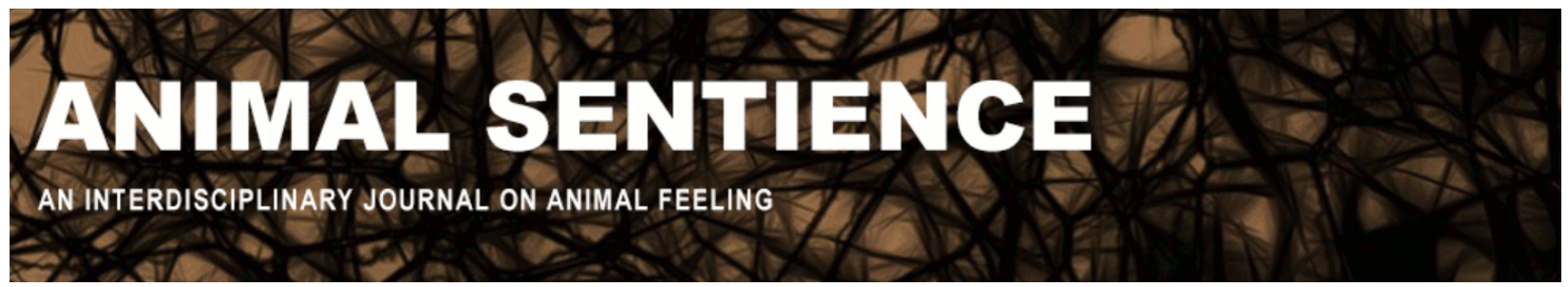

Reber, Arthur S. (2018) Sentient plants? Nervous minds?. Animal Sentience 11(17)

DOI: $10.51291 / 2377-7478.1307$

Date of submission: 2018-02-09

Date of acceptance: 2018-02-15

(c)

This article has appeared in the journal Animal

Sentience, a peer-reviewed journal on animal

cognition and feeling. It has been made open access,

free for all, by WellBeing International and deposited

in the WBI Studies Repository. For more information,

please contact

wbisr-info@wellbeingintl.org.

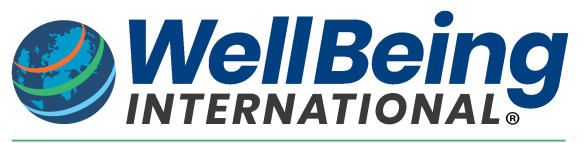

SOLUTIONS FOR PEOPLE, ANIMALS AND ENVIRONMENT 


\title{
Sentient plants? Nervous minds?
}

Response III to Commentary on Reber on Origins of Mind

\author{
Arthur S. Reber \\ Department of Psychology \\ University of British Columbia
}

\begin{abstract}
The commentaries by Calvo (2018) and Mallatt \& Feinberg (2017) on my 2016 target branch out from a common conceptual node like forks in a road. Calvo criticizes me for not acknowledging that plants too are likely to be sentient and claims I have fallen into the kind of category error of which I accuse others - a zoocentric bias that fails to grant consciousness to flora. Mallatt \& Feinberg maintain that I've gone too far in granting sentience to any species that lacks a nervous system. Calvo makes some good points but there are other issues concerning plant sentience such as metabolic cost and ethical implications. Mallatt \& Feinberg take me to task for failing to provide supporting data. They are right, and a partial remedy is offered. They also imply that I have misunderstand basic principles of evolutionary biology. I think they have misunderstood my position.
\end{abstract}

Arthur S. Reber is Broeklundian Professor of Psychology, Emeritus, Brooklyn College and Graduate Center of the City University of New York, and currently Visiting Professor, Psychology, University of British Columbia. His research is on implicit learning, the process through which knowledge about the world about us is picked up largely independently of awareness of both the process and products of that learning. academic.brooklyn.cuny.edu/userhome/psych/areber/

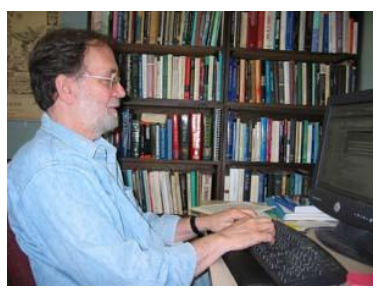

First, let me note that the target article (Reber, 2016) was an effort to convey the skeletal framework of the CBC (Cellular Basis of Consciousness) model. It was not, and could not possibly have been, a thorough analysis of these issues. These (and many other) issues (similarly vexing and challenging) are dealt with in detail in Reber (2018, in press). Lacking space to fully develop arguments which are complex and detailed, I'll briefly address here the key points of Calvo and Mallatt \& Feinberg.

\section{Plant Sentience}

Some excellent points are made by Calvo. The case for some form of consciousness in plants is becoming stronger by the day. We're still a way from any hard conclusions, but I acknowledge these research findings. There is also another element in the argument that Calvo doesn't touch on - nor do his collaborators or others whose work he cites such as František Baluška (2016) and Anthony Trewavas (2017): the conservative nature of evolution. And it's one that could be argued as supporting their thesis.

Once a trait, a form, a function, or process has evolved and shown itself to have adaptive value, it is exceedingly rare for it to be lost as other species evolve and branch off. 
In fact, this jettisoning of an adaptive characteristic is so rare that when biologist Philippe Janvier's (2010) genetic analyses of hagfish and lampreys showed conclusively that the hagfish did indeed lose its spine, he referred to it as an instance of a "spectacular degeneracy." If the CBC model is correct and prokaryotes are sentient, then by the simple fact that plants evolved later, they should have retained their capacity for sentience.

There is an additional factor that needs to be brought into the equation, however: the metabolic expense of sentience. In single-celled motile species, sentience is an essential feature, particularly when dealing with an environment in constant flux. The molecular nature and concentration of the nutrients in the surrounding medium is constantly shifting; temperature gradients are changing; the nature and valence of objects - from other organisms and toxins to predators - is continuously shifting. Without having an awareness, a subjective representation of these changes, without being able to make decisions - about where to move, how to shift gene-expression (for example, from being prepared to metabolize lactose rather than maltose when the sugars in the environment change), how to compare current ambient temperature with the memory of what it was in a previous location so as to determine whether to more forward or backward - a prokaryote would be a Darwinian dead-end. Sentience is essential.

But it is metabolically expensive; there's a lot of biological cost invested in being able to key in on, represent, and react to these many features of the environment. If a species lays down roots, abandons its motile ways, it may just find that this aspect of existence is no longer worth the biological effort. It might turn out to be more effective, from a natural selection point of view, to focus instead on other forms and functions, ones that have a more immediate evolutionary benefit.

I am not saying that this is what happened. I am simply considering the possibility that when that chimeric symbiogenetic alga first appeared and initiated the sessile existence of flora, it initiated the process of abandoning sentience. The issue is, ultimately, an empirical one. Although I took an anti-plant-sentient stance in the target article, ultimately, I am agnostic on the issue. The validity of the CBC is independent of whether plants are sentient. For Calvo, Sahi, \& Trewavas (2017), who work in the area they have dubbed "plant neurobiology," however, the issue poses a number of other problems - problems with ethical overtones that I have yet to see addressed. If they are right, ethical vegetarians and vegans are going to have to confront some uncomfortable propositions. Again, there is a section in Reber (2018) that discusses these issues from a utilitarian standpoint

\section{Nervous Minds}

According to Mallatt \& Feinberg (M\&F), a nervous system, no matter how primitive, is necessary and sufficient for the emergence of (any of several possible forms of) consciousness. This position, which is common among cognitive neuroscientists and philosophers of mind (e.g., Dennett, 2017; Harnad, 2016; Key, 2016a,b) has, underlying it, the proposition that all the behaviors observed in organisms that lack (the right kinds of) neural systems are mechanical in nature and driven by genetic programs that operate bereft of subjectivity. There is, from this perspective, "nothing it is like to be a neuron-free species." They have all the awareness of the world about them of a toaster. As Dennett (2017) put it, they have "competence" but no "comprehension." 
In their commentary, $\mathbf{M} \& \mathbf{F}$ note that while the CBC model, as presented in my target article, has some intriguing elements (e.g., skirting dualism and deflecting panpsychism), they have problems with it. Let me say that I agree with many of their criticisms. They note, for example, that "Too little evidence is given to support such an iconoclastic claim." This is true. They maintain that I've behaved in an unscientific manner and that "... the burden of proof is on Reber as the claimant to find and master the scientific literature pertaining to his claim." This is somewhat less true - but I appreciate the point. As with the issues raised in Calvo's commentary, I simply didn't have the room to present the data. In Reber (2018), there is a thorough review of prokaryotic mental capacity including:

1. A detailed exploration of the classic studies of Jennings (1906) showing compelling evidence of avoidance learning in the single-celled eukaryote Stentor roeseli.

2. Mascher, Helmann, and Unden's (2006) work on the several mechanisms in bacteria that use "signal-transducing systems" based on kinases that sit on the cell membrane and detect (i.e., sense) particular environmental stimuli and pass the information onto an internal regulatory system that mediates the cell's response in appropriate ways (i.e., perceives). Mascher et al. specifically characterize these mechanisms as ones that allow prokaryotes to perceive and interpret the valences of sensory inputs.

3. Mitchell et al.'s (2009) finding that both E. coli and a yeast, Saccharomyces cerevisiae, can learn to "foresee" (their term) forthcoming events and begin responding prior to their onset. They repeatedly presented lactose to both species, followed soon afterward by maltose. Over time the bacteria made anticipatory adjustments in metabolic function to process maltose more efficiently. This was genuine learning of a stimulus-stimulus pairing and not simply sensitization. When they switched the order and presented maltose first, the bacteria failed to show the metabolic adaptation.

4. Mathis and Ackermann's (2016, 2017) demonstration of relatively long-term memory in bacteria. They subjected cells to several waves of an aversive, concentrated salt solution before cell division. Then, after division - and after the daughter cells had relocated - they reintroduced the toxic salts. The resulting cell death rate in the population of mother cells was significantly lower than among the daughter cells, and this prophylactic effect lasted up to two hours. The bacteria that stayed in the same environment retained a mental representation of events there and showed a readiness to make appropriate metabolic shifts to deal with the toxic salts should they recur. The motile daughter cells, the ones that left for a new and presumably safe location, had no need to hold on to a memory of the earlier events and failed to make the same kinds of metabolic adjustments. As a result, they succumbed at a higher rate - despite having identical genetic makeup.

5. Computational physicist Jané Kondev's (2014) explorations of diet-selection functions in bacteria where the data were sufficiently compelling to provoke him to ask the question, "Does E. coli have free will?"

6. There is (much) more here, including decision-making operations, clear demonstrations of affect, both within- and between-colony communication among prokaryotes, and the remarkable report from Gürol Süel's lab of evidence for a primitive form of altruistic cooperation (see Prindle et al., 2015, for details).

For a motile organism living in an ever-changing environment, such a range of functions requires sentience: awareness of self as an existential element. $\mathbf{M} \& \mathbf{F}$ say the burden of proof for attributing sentience to unicellular organisms falls upon those who make such claims. They are right. It does; and I've tried to adduce the evidence. But there is a burden critics 
must shoulder as well: to present some principled reason(s) conscious experience cannot exist without a nervous system.

M\&F also make some comments about my position and the manner in which it is developed that I found troublesome - though I suspect that if/when they get a chance to read Reber (2018), we may all find that the disagreements are minor or nonexistent. For example, they state: "These principles appear to presuppose that evolution proceeds in a straight line from simple to complex as if directed up a pyramid."

There is nothing in my pyramid metaphor that implies a "straight line" of evolution, and there is certainly no claim that any of it is "directed." It simply uses the conceptual design feature of having a firm foundation upon which additional forms and functions evolve. No directionality is implied. It's also a scaffolding that uses formal logical and evolutionary biological principles. There is no constraint on the manner of variation within levels. There is no principle that says evolution must move up levels. There are no implied restrictions on the development of novel forms and functions. The details can be found in Reber (1993) and Schank and Wimsatt (1988).

And this: "If Reber (and Velmans, 2016) were to apply their non-emergent arguments to life, they would have to say life could not have evolved step-by-step because it could not have blinked into existence instantaneously from a nonliving entity." I won't speak for Velmans here but assigning this conclusion to me is just off the mark. Of course, life "blinked into existence." We don't know if it was "instantaneous" or the result of an accretion of prebiotic functions that reached some kind of existential threshold. Likely the latter.

There's an "origin of life" sub-discipline within biology where issues such as these are actively researched. John Sutherland and coworkers, for example, recently identified a route through which RNA could have formed without the need for enzymes (see Patel et al., 2015, for details). They've managed to create precursors of nucleic acid with rather mundane molecules like hydrogen cyanide and hydrogen sulfide and a bit of ultraviolet light. And it's quite likely that other similar "short-cuts" to life will be uncovered in years to come. All I am claiming is that when these problems get worked out, we are almost certainly going to see that the initial (and only) emergence of sentience accompanied the first biotic forms.

Finally, I am aware of the excellent work that Feinberg \& Mallatt (2016) have done in the neurosciences. Their model is discussed at length in Reber (2018) as is the notably similar theory of Barron and Klein (2016).

\section{References}

Baluška, F. (2016). Should fish feel pain? A plant perspective. Animal Sentience 3(16).

Barron, A. B., \& Klein, C. (2016). What insects can tell us about the origins of consciousness. Proceedings of the National Academy of Sciences, 113, 4900-4908.

Calvo, P. (2018). Caterpillar/basil-plant tandems. Animal Sentience 11(16).

Calvo, P., Sahi, V. P., \& Trewavas, A. (2017). Are plants sentient? Plant, Cell \& Environment, 40, 2858-2869.

Dennett, D. C. (2017). From Bacteria to Bach and Back: The Evolution of Minds. NY: Norton.

Feinberg, T. E., \& Mallatt, J. (2016). The nature of primary consciousness. A new synthesis. Consciousness and Cognition, 43, 113-127. 
Harnad, S. (2016). Animal sentience: The other-minds problem. Animal Sentience 1(1). Janvier, P. (2010). MicroRNA's revive old views about jawless vertebrate divergence and evolution. Proceedings of the National Academy of Sciences, 107, 19137-19138.

Jennings, H. S. (1906). The Behavior of the Lower Organisms. NY: Columbia University Press. Key, B. (2016a). Why fish do not feel pain. Animal Sentience 3(1).

Key, B. (2016b). "Cellular basis of consciousness": Not just radical but wrong. Animal Sentience 11(5).

Kondev, J. (2014). Bacterial decision making. Physics Today, 67, 31-37.

Mallatt, J., \& Feinberg, T. E. (2016). Consciousness is not inherent in but emergent from life. Animal Sentience 11(15).

Mascher, R., Helmann, J. D., \& Unden, G. (2006). Stimulus perception in bacterial signaltransducing histidine kinases. Microbiological Molecular Biology Review, 70, 910-938.

Mathis, R., \& Ackermann, M. (2016). Response of single bacterial cells to stress gives rise to complex history dependence at the population level. Proceedings of the National Academy of Sciences, March 7, 2016 DOI: 10.1073/pnas.1511509113.

Mathis, R., \& Ackermann, M. (2017). Asymmetric cellular memory in bacteria exposed to anti-biotics. BMC Evolutionary Biology, https://doi.org/10.1186/s12862-017-0884-4.

Mitchell, A., Romano, G. H., Groisman, B., Yona, A., Dekel, E., Kupiec, M., Dahan, O., \& Pilpel, Y. (2009). Adaptive prediction of environmental changes by microorganisms. Nature, 460, 220-224.

Patel, B. H., Percivalle, C., Ritson, D. J., Duffy, C. D., \& Sutherland, J. D. (2015). Common origins of RNA, protein and lipid precursors in a cyanosulfidic protometabolism. Nature Chemistry, 7, 301-307.

Prindle, A., Liu, J., Asally, M., Ly, S., Garcia-Ojalvo, J., \& Süel, G. M. (2015). Ion channels enable electrical communication in bacterial communities. Nature, 527, 75-76.

Reber, A. S. (1993). Implicit Learning and Tacit Knowledge: An Essay on the Cognitive Unconscious. NY: Oxford University Press.

Reber, A. S. (2016). Caterpillars, consciousness and the origins of mind. Animal Sentience 11(1).

Reber, A. S. (2018, in press). The First Minds: What I Learned from Conversations with a Caterpillar and Some Sentient Cells. Oxford University Press.

Schank, J. C., \& Wimsatt, W. C. (1988). Generative entrenchment and evolution. In A. Fine \& P. Machamer (Eds.), PSA 1986: Proceedings of the Meetings of the Philosophy of Science Association. East Lansing, MI: Philosophy of Science Association.

Trewavas, A. (2017). The foundations of plant intelligence. Interface Focus: Journal of The Royal Society, 7, 20160098.

Velmans, M. (2016). How could consciousness emerge from adaptive functioning? Animal Sentience 11(6). 


\section{UQÀM/ISC Cognitive Science Summer School June 26 - July 6 2018, Montreal, Canada}

\section{The Other Minds Problem: Animal Sentience and Cognition}

Overview. Since Descartes, philosophers know there is no way to know for sure what - or whether - others feel (not even if they tell you). Science, however, is not about certainty but about probability and evidence. The 7.5 billion individual members of the human species can tell us what they are feeling. But there are 9 million other species on the planet (20 quintillion individuals), from elephants to jellyfish, with which humans share biological and cognitive ancestry, but not one other species can speak: Which of them can feel - and what do they feel? Their human spokespersons - the comparative psychologists, ethologists, evolutionists, and cognitive neurobiologists who are the world's leading experts in "mind-reading" other species -- will provide a sweeping panorama of what it feels like to be an elephant, ape, whale, cow, pig, dog, bat, chicken, fish, lizard, lobster, snail: This growing body of facts about nonhuman sentience has profound implications not only for our understanding of human cognition, but for our treatment of other sentient species.

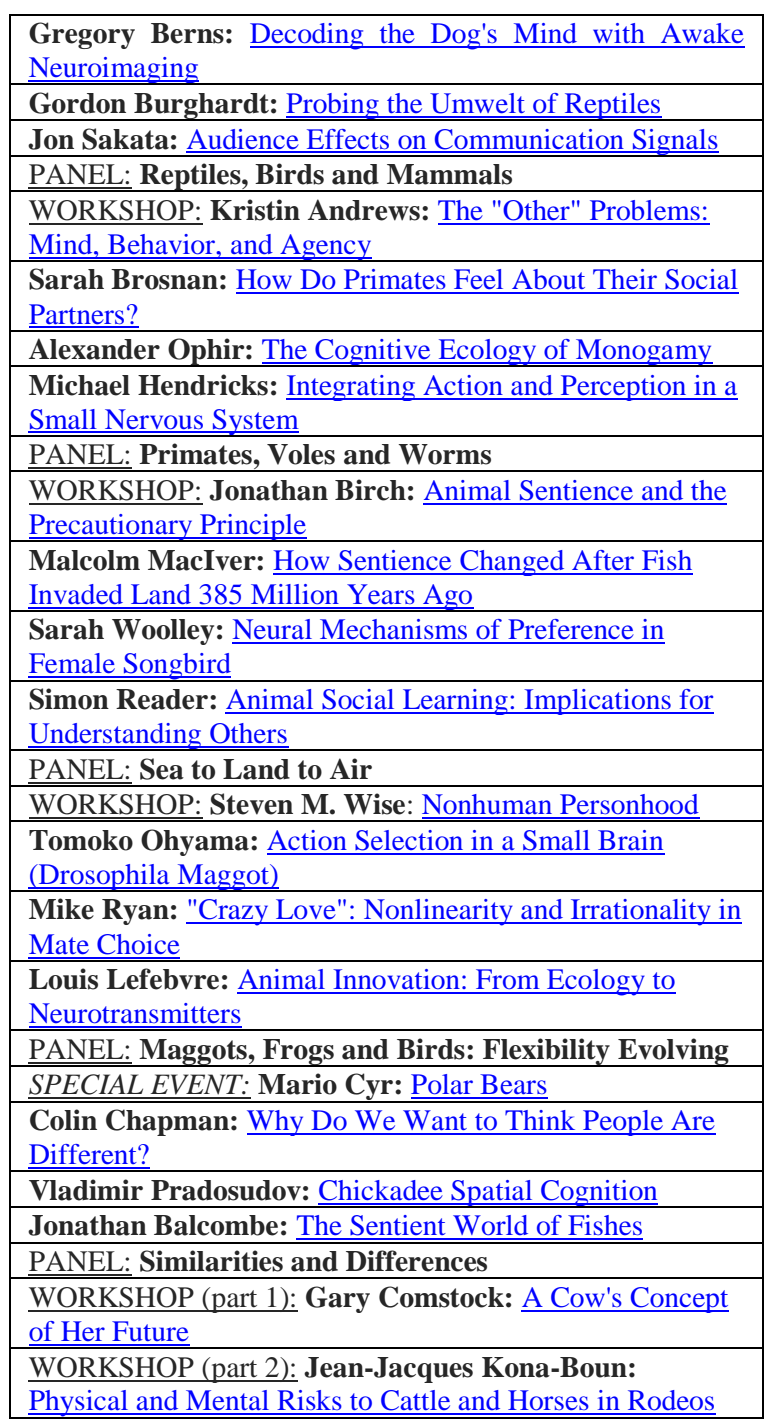

\begin{tabular}{|c|}
\hline $\begin{array}{l}\text { Joshua Plotnik: Thoughtful Trunks: Application of } \\
\text { Elephant Cognition for Elephant Conservation }\end{array}$ \\
\hline Lori Marino: Who Are Dolphins? \\
\hline PANEL: Mammals All, Great and Small \\
\hline $\begin{array}{l}\text { Larry Young: The Neurobiology of Social Bonding, } \\
\text { Empathy and Social Loss in Monogamous Voles }\end{array}$ \\
\hline $\begin{array}{l}\text { WORKSHOP: Lori Marino: The Inconvenient Truth } \\
\text { About Thinking Chickens }\end{array}$ \\
\hline $\begin{array}{l}\text { Andrew Adamatzky: Slime Mould: Cognition Through } \\
\text { Computation }\end{array}$ \\
\hline $\begin{array}{l}\text { Frantisek Baluska \& Stefano Mancuso: What a Plant } \\
\text { Knows and Perceives }\end{array}$ \\
\hline $\begin{array}{l}\text { Arthur Reber: A Novel Theory of the Origin of Mind: } \\
\text { Conversations With a Caterpillar and a Bacterium }\end{array}$ \\
\hline PANEL: Microbes, Molds and Plants \\
\hline $\begin{array}{l}\text { WORKSHOP: Suzanne Held \& Michael Mendl: Pig } \\
\text { Cognition and Why It Matters }\end{array}$ \\
\hline James Simmons: What Is It Like To Be A Bat? \\
\hline Debbie Kelly: Spatial Cognition in Food-Storing \\
\hline Steve Phelps: Social Cognition Across Species \\
\hline PANEL \\
\hline WORKSHOP: To be announced \\
\hline Lars Chittka: The Mind of the Bee \\
\hline $\begin{array}{l}\text { Reuven Dukas: Insect Emotions: Mechanisms and } \\
\text { Evolutionary Biology }\end{array}$ \\
\hline $\begin{array}{l}\text { Adam Shriver: Do Human Lesion Studies Tell Us the } \\
\text { Cortex is Required for Pain Experiences? }\end{array}$ \\
\hline PANEL \\
\hline $\begin{array}{l}\text { WORKSHOP: Delcianna Winders: Nonhuman Animals } \\
\text { in Sport and Entertainment }\end{array}$ \\
\hline $\begin{array}{l}\text { Carel ten Cate: Avian Capacity for Categorization and } \\
\text { Abstraction }\end{array}$ \\
\hline Jennifer Mather: Do Squid Have a Sense of Self? \\
\hline $\begin{array}{l}\text { Steve Chang: Neurobiology of Monkeys Thinking About } \\
\text { Other Monkeys }\end{array}$ \\
\hline PANEL \\
\hline $\begin{array}{l}\text { WORKSHOP: The Legal Status of Sentient Nonhuman } \\
\text { Species }\end{array}$ \\
\hline
\end{tabular}

